\title{
Professionalism: How payment models affect physician behaviour
}

$\mathrm{L}$ ike all working stiffs, doctors have mouths to feed and bills to pay. And green fees at golf courses aren't getting any cheaper. Though some might argue that many doctors, specialists in particular, have incomes bordering on the obscene, no reasonable person would suggest that physicians don't have a right to make a living.

How doctors are paid, however, is a topic of perpetual debate. There are many compensation models, all with supporters and detractors. There is little question, though, that the means by which doctors are paid affects how they practise medicine - sometimes in ways that conflict with core elements of medical professionalism.

Consider the fee-for-service payment model, which compensates physicians according to the quantity of care they provide. A major tenet of medical professionalism is to put the health needs of the patient ahead of the financial needs of the doctor. But aligning pay with throughput creates a financial incentive to provide more care, not optimal care. To paraphrase the thoughts of a bloated diner leaving an all-you-can-eat buffet: more isn't always better.

"Just giving people more, more, more isn't necessarily good for them," says Dr. Marissa Hendrickson, assistant professor of pediatric emergency medicine and a staff physician at the University of Minnesota Amplatz Children's Hospital in Minneapolis.

Perhaps, then, a payment scheme based on tracking quality of care would more closely adhere to the principles of medical professionalism. Well, that's the exact topic Hendrickson explored in her paper "Pay for Performance and Medical Professionalism" (Qual Manag Health Care 2008;17:9-18).

Under a pay-for-performance (P4P) plan, compensation is linked to meeting a predetermined set of quality metrics. By

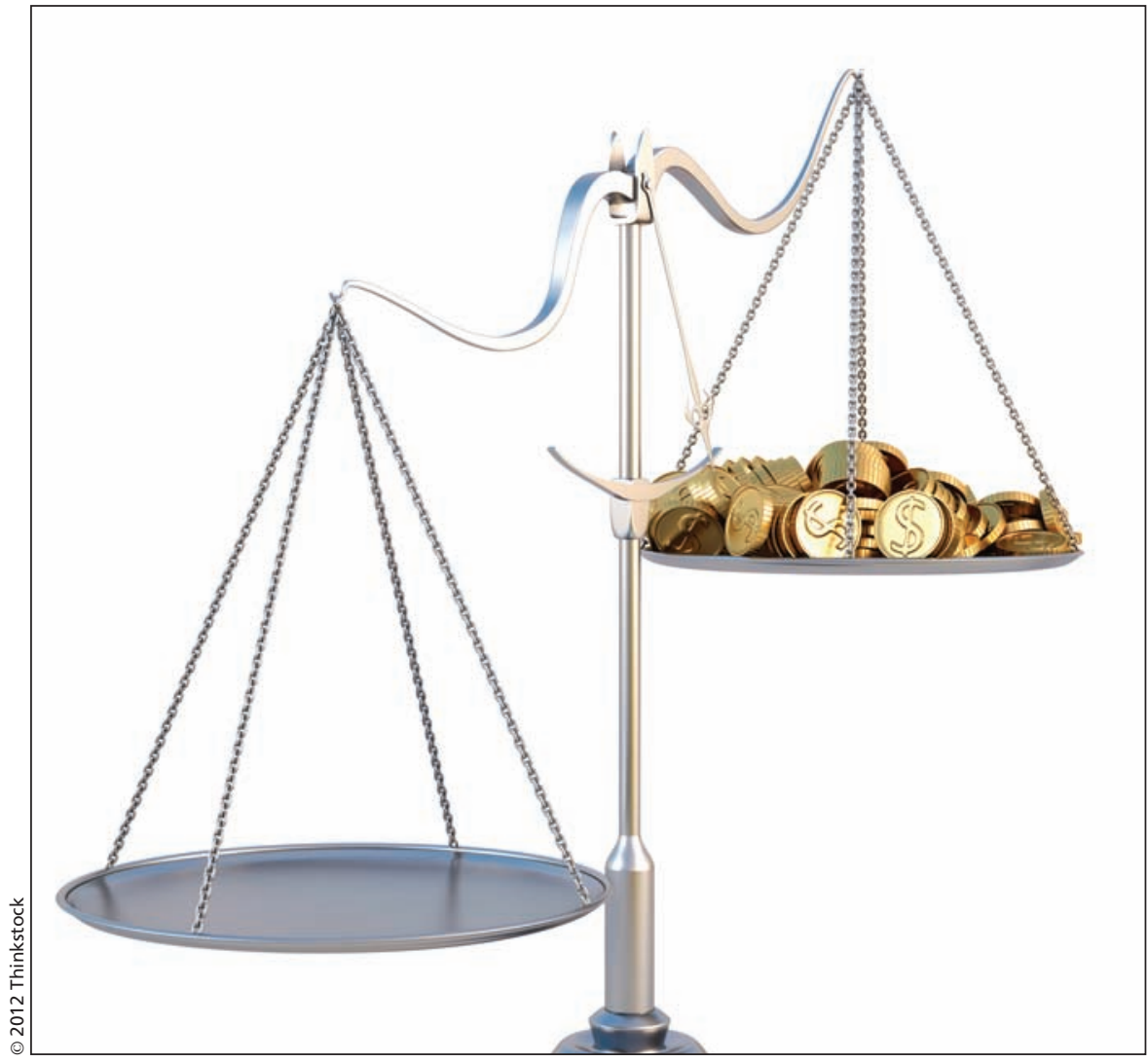

A major tenet of medical professionalism is to put the health needs of the patient ahead of the financial needs of the doctor.

focusing on patient outcomes rather than patient traffic, the theory goes, the financial incentive shifts from providing more care to providing better care. It is considered by some to be a practical approach to harnessing self-interest, a trait that affects all people, even those with stethoscopes hanging around their necks.

"If all physicians were perfectly self-sacrificing, payment schemes would have no effect on practice," wrote Hendrickson. "However, given that financial realities do at times have an effect on physicians' behavior, the $\mathrm{P} 4 \mathrm{P}$ movement seeks to turn this weakness into a strength, exploiting physicians' desire for financial gain in service to patients."

But it turns out this model is no panacea. The main problem lies in how a system is set up. If it tracks and promotes particular procedures and treatments, there will be a natural tendency to boost those numbers. This could lead to health care decisions being made, consciously or otherwise, on what best serves the payment system rather than the patient. And that, without question, is a big-time professionalism no-no.

"The biggest fear is if people were paid more for limiting the use of certain tests or treatments," says Hendrickson.

In the United States, pay-forperformance schemes have often been backed by for-profit insurance companies or corporate purchasers of health plans. That brings corporate shareholders into the picture, who, rumour has it, have a keen interest in maximizing profits. They also aren't averse to 
reducing costs - like those associated with, say, providing adequate health care to employees.

That's not to say, of course, that containing costs is anathema to medical professionalism. The reduction of wasteful spending on unnecessary care can benefit not only payers, but also the public particularly in countries, such as Canada, where the public is the payer. Still, it may be naive to think that corporate interests - including those that don't jive with medical professionalism - have little impact on clinical care.

"Private insurers are parasites on the US health care system," says Dr. Arnold Relman, professor emeritus of medicine and social medicine at Harvard Medical School in Boston, Massachusetts, and former editor-in-chief of the New England Journal of Medicine. "There has been a terrible exploitation of the American health care system by private insurers. We need to phase out private insurers and have a single-payer system."

Another method of paying physicians is to use a capitation model, which pays a set amount for each patient, regardless of the amount of care received. But any scheme with a cap creates an incentive to cut costs, possibly by limiting care or avoiding patients with complex medical conditions. "That provides an ugly and profound disincentive for providing adequate care," says Hendrickson.

A possible alternative to fee-based systems is to pay physicians a salary. Perhaps encouraging more doctors to join large, group practices and putting them on payrolls would allow them to concentrate more on patients' needs and less on earning money. Then the challenge becomes setting a reasonable amount for doctors to take home at the end of each day. "When you set up the rules for a group practice, you decide that only ' $\mathrm{X}$ ' \% of group practice income can be used for doctors' salaries," says Relman.

No matter which compensation system a health care organization adopts, it is important that efforts be made to align incentives, as much as possible, with the professional ideals of medical practice. "The critical factor in reconfiguring measurement and payment schemes is that systems not be designed in a way that forces wellmeaning physicians to work against illconceived incentives, or that require they sacrifice their livelihoods to stay true to their professional responsibilities," wrote Hendrickson, adding that payers "should not be the strongest leaders in the struggle to advance medical quality; the profession must recapture for itself the critical functions of determining what constitutes excellent care and ensuring that everyone receives it."

Of course, there is no perfect payment model and likely never will be. In her paper, Hendrickson quotes a physician who suggested there were three types of compensation systems: "Last year's, which everybody hated. This year's, which nobody likes. And next year's, which is the perfect answer." In an ideal system, the healthier the patient, the wealthier the doctor. But it's one thing to propose such a system, says Hendrickson, and quite another to implement it. "The devil is in the details of how you could design such a thing." - Roger Collier, CMAJ

CMAJ 2012. DOI:10.1503/cmaj.109-4250

Editor's note: Ninth in a multipart series on medical professionalism.

Part I: The "good doctor" discussion (www.cmaj.ca/lookup/doi/10.1503/cm aj.109-4200).

Part II: What is it? (www.cmaj.ca /lookup/doi/10.1503/cmaj.109-4211).

Part III: The historical contract (www.cmaj.ca/lookup/doi/10.1503 /cmaj.109-4230).

Part IV: Can it be taught?

(www.cmaj.ca/lookup/doi/10.1503 /cmaj.109-4232).

Part V: Social media outreach (www.cmaj.ca/lookup/doi/10.1503 /cmaj.109-4207).

Part VI: Social media mishaps (www.cmaj.ca/lookup/doi/10.1503 /cmaj.109-4209).

Part VII: Logging on to tell your doctor off (www.cmaj.ca/lookup /doi/10.1503/cmaj.109-4205).

Part VIII: Assessing physician behaviour (www.cmaj.ca/lookup/doi /10.1503/cmaj.109-4240). 